\title{
Implementasi Program Penguatan Pendidikan Karakter (PPK) Dalam Pembelajaran Pendidikan Agama Islam (Studi Deksriptif di SD Rusyda Medan)
}

\author{
Haidir*1, Media Gusman², Nona Kumala Sari \\ Universitas Muslim Nusantara Al-Washilyah*1 \\ UIN Sumatera Utara Medan ${ }^{2}$ \\ STAI Sumatera Medan ${ }^{3}$ \\ ${ }^{*}$ email: haidir@umnaw.ac.id \\ 2 email: medyasikumbang734@gmail.com \\ 3email:nona27kumalasari@gmail.com
}

\begin{abstract}
This study aims to analyze (1) implementation of character education strengthening programs in learning, (2) Implementation of character education strengthening programs outside of learning, (3) factors encountered in implementing character education strengthening programs in SD Rusyda medan. The research method used is a qualitative research method with a descriptive study approach. The results of the study indicate that SD Ruydda Medan has implemented the provisions of Perpres No. 87 of 2017. In character learning is packaged in the form of material that is explained in harmony with other subject matter. These character values are contained in the teacher learning tool, which is therefore not just insert material, but becomes material that has its own target achievement. Meanwhile outside program learning takes place in activities that involve physical activities such as flag ceremonies, and extracurricular activities such as scouting, arts and martial arts. Constraints faced are the lack of training from the ministry of education on character education strengthening programs, the lack of teacher and parent collaboration on character education.
\end{abstract}

Keywords: Education, Character, PAI.
Artikel Info

Received:

05 April 2020

Revised:

18 April 2020

Accepted:

23 May 2020

Published:

05 June 2020

\begin{tabular}{l}
\hline \multicolumn{1}{c}{$\boldsymbol{A b s t r a k}$} \\
\hline Penelitian ini bertujuan untuk menganalisis (1) \\
implementasi program penguatan pendidikan karakter dalam \\
pembelajaran, (2) Implementasi program penguatan \\
pendidikan karakter diluar pembelajaran, (3) faktor-faktor
\end{tabular}


yang dihadapi dalam pemngimplementasian program penguatan pendidikan karakter di SD Rusyda medan. Metode penelitian yang dipergunakan ialah metode penelitian kualitatif dengan pendekatan studi deskriptif. Adapun hasil penelitian menunjukkan bahwa SD Rusyda medan telah melaksanakan ketentuan Peraturan presiden No. 87 tahun 2017. Dalam pembelajaran karakter dikemas dalam bentuk materi yang dijelaskan selaras dengan materi pelajaran lain. Nilai-nilai karakter tersebut tertera dalam perangkat pembelajaran guru, dengan demikian bukan sekedar materi sisipan, tetapi menjadi materi yang memiliki target pencapaian tersendiri. Sedangkan di luar pembelajaran, program terlaksana dalam kegiatan yang melibatkan aktivtas fisik seperti upacara bendera, dan kegiatan ekstrakurikuler seperti pramuka, seni dan bela diri. Kendala yang dihadapi ialah kurangnya pelatihan dari kementerian pendidikan tentang program penguatan pendidikan karakter, kurangnya kerjasama guru dan orang tua tentang pendidikan karakter.

Kata kunci: Pendidikan, Karakter, PAI.

\section{A. Pendahuluan}

Pendidikan merupakan sistem yang sistematis dan kompleks yang memiliki visi dan misi dengan cakupan apek yang luas sekali, mulai dari pengembangan aspek fisik, psikis, koginitif, afektif, psikomotorik, sosial, bahkan juga dalam cakupan aspek spritualitas atau yang berkaitan dengan keimanan. Hal ini lah yang membuat beratnya beban lembaga pendidikan, baik sekolah maupun madrasah. Bahkan jika dikaitkan dengan masa kini beban tersebut menjadi sangat berat, sebab saat ini manusia berevolusi dalam pemikiran, bersikap maupun berperilaku (Majid \& Andayani, 2011).

Banyak orang mengatakan bahwa kehidupan zaman modern sangat berbeda dengan kehidupan zaman dahulu. Perbedaan utama yang selalu menjadi perbincangan adalah aspek dekadensi moral. Tidak diketahui secara pasti kapan orang-orang mulai memperbincangkan itu, tetapi yang pasti hingga detik ini, dekadensi moral hampir terjadi di seluruh pelosok negeri. Tidak hanya di kota, pinggiran kota, bahkan di pedesaan semuanya nyaris tak luput dari dekadensi. 
Menyadari akan hal ini, para orang tua berusaha semaksimal mungkin untuk melindungi anaknya agar tidak terjerumus ke dalam lembah dekadensi tersebut. Banyak cara dilakukan termasuk memberikan pendidikan yang cukup. Dengan menyekolahkan anak sampai jenjang pendidikan tertinggi, diharapkan anak memiliki bekal yang matang untuk dapat menjalani hidup dan berhubungan baik dengan sesama. Tak peduli berapa uang yang harus dikeluarkan, yang terpenting bisa sampai pada jenjang pendidikan tinggi (Lubis, 2018).

Tetapi persepsi itu saat ini menuai keraguan, beberapa kasus dekadensi moral saat ini malah ditunjukkan oleh individu dengan jenjang pendidikan tinggi. Korupsi misalnya, pejabat negeri yang terlibat kasus ini bukanlah orang yang tak berpendidikan, bahkan dapat digelari sebagai tokoh pendidikan. Contoh lainnya kasus plagiasi, kini marak dipraktekkan di institusi, dan menjadi mata pencaharian tambahan. Kolusi, nepotisme, gratifikasi, money laundry, dan masih banyak lagi kasus keburukan yang dikakukan oleh aktor-aktor berpendidikan (Koesoema, 2007).
Efek dari dekadensi moral ini tidak hanya dirasakan oleh individunya, tetapi juga merusak moral dan citra bangsa ini. Sebab citra suatu bangsa erat kaitannya dengan karakter generasinya. Suatu bangsa akan dipandang sebagai Negara yang yang bermartabat dan kuat apabila memiliki karakter yang bermartabat juga. Dengan begitu ia akan disegani oleh bangsa-bangsa lain. Maka wajar jika setiap Negara memiliki program untuk peningkatan karakter bangsa (Wibowo, 2012).

Menyadari parahnya akibat yang ditimbulkan hal tersebut, pemerintah dalam Rencana Pembangunnan Jangka Panjanng Nasional Tahunn 2005-2025, menjadikan 'pembinaan karakter' sebagai misi utama dari 8 misi yang direncanakan (Chaniago, 2015). Berbagai macam diskusi pun dilakukan di berbagai kegiatan untuk merumuskan arah dan kebijakan tentang cara menangkal dekadensi moral tersebut. Akhirnya kesepakatanpun bermuara pada pembentukan dan penanaman karakter kepada bangsa, yang salah satunya melalui sektor pendidikan.

Seiring dengan perkembangan, pendidikan karakter saat ini berada pada era yang baru, salah satunya dilihat dari kemunculan Perpres RI No. 87 Tahun 
Vol. 12, No. 1 (June 2020)

2017 tentang Pengguatan Pendidikan

Karakterr atau PPK. Perpres ini bermuatan tentang keputusan program pendidikan yang ditanggung jawabi oleh satuan pendidikan dalam hal pembinaan karakter anak bangsa melalui harmonisasi kegiatan olah raga, olah pikir, olah rassa, serta megikutsertakan peran keterlibatan keluarga, masayarakat sebagai gerakan nasional, dan bagian dari gerakan revolusi mental (GNRM). Gerakan ini muncul sebagai bagian dari kebijakan bidang pendidikan yang tujuan terpentingnya ialah mengimplementasikan program Nawacita Presiden dalam Sisdiknas. Gerakan ini akan mendorong generasi agar memiliki kemampuan berpikir, bersikap serta bertindak dengan baik sesuai tuntutan kebutuhan bangsa, dan tuntuan perubahan zaman (Lubis, Implementasi, Program Penguatan Pendidikan karakter (PPK) dalam pembelajaran Penddikan afama Islam, 2019).

Poin utama dari gerakan PPK ini ada lima yakni relgius, Nasionalis, Mandiri, Gotong royong, dan Integritas. Kelima nilai tersebut menjadi pilar utama yang harus dikembangkan dalam dunia pendidikan. Sebab dunia pendidikanlah yang menjadi garda utama dalam penegakan dan pembinaan moral dan karakter. Hal lain yang mendasari munculnya hal ini adalah karena begitu besarnya tantangan bangsa yang dihadapi di masa-masa mendatang. Tidak hanya itu, tetapi juga didasari oleh keinginan dan cita-cita yang besar terhadap masa depan bangsa ini. Untuk itulah Kepala Sekolah sebagai perpanjangantangan pemerintah menjadi penanggungjawab utama dalam menerapkannya menerapkannya sesuai dengan konteks dan kekhasan daerahnya masing-masing, namun tetap Perpres tersebut menjadi rujukan utamanya (Nurussakinah Daulay, 2019).

Perlu diketahui bahwa tujuan program Penguatan Pendidikan Karakter (PPK) adalah menanamkan nilai-nilai pembentukan karakter bangsa secara massif dan efektif melalui implementasi nilai-nilai utama Gerakan Nasional Revolusi Mental (religius, nasionalis, mandiri, gotong-royong dan integritas) yang akan menjadi fokus pembelajaran, pembiasaan, dan pembudayaan, sehingga pendidikan karakter bangsa dapat mengubah perilaku, cara berpikir dan cara bertindak seluruh bangsa Indonesia menjadi lebih baik dan berintegritas. 
Vol. 12, No. 1 (June 2020)

Namun di tengah semangatnya

para pendidik untuk memperbaiki karakter dan kepribadian anak-anaknya, masih banyak yang tidak memahami arah dari pendidikan karakter itu sebenarnya. Keinginan pemerintah dengan hadirnya Perpres PPK tersebut tentu pada dasarnya sangat sederhana saja, yakni agar terdapat pemerataan dan keseragaman terhadap karakter anak bangsa.

SD Rusyda Medan termasuk salah satu institusi pendidikan yang sudah menerapkan PPK tersebut. Hal ini sebagai wujud implemetasi dari Perpres No. 87 tahun 2017, tentu sepanjang penerapannya banyak hal-hal baru terkait dengan implementasinya dan problematika yang dihadapi.

Berdasarkan uraian masalah di atas, maka tujuan penelitian ini ialah untuk menganalisis model implementasi pendidikan karakter dalam pembelajaran, di luar pembelajaran, serta faktor-faktor yang dihadapi dalam pengimplementasian pendidikan karakter di SD Rusyda medan.

\section{B. Metode Penelitian}

\section{Lokasi dan Waktu Penelitian}

Penelitian ini berlokasi di SD Rusyda Medan yang beralamat di jalan
Bromo Gg. Satia No. 5 Kel. Binjai Kecamatan Medan Denai Kota Medan. Alasan pemilihan lokasi penelitian ini atas dasar SD ini telah mengimplemtasikan proggram Penguatan Pendidikan Karakter (PPK) sebagaimana yang telah diamanahkan dalam Peraturan Presiden No. 87 tahun 2017. Selain itu sebagian guru telah mengikuti pelatihan dan sosialisasi tentang gerakan nasional Penguatan Pendidikan Karakter (PPK) yang diadakan oleh Kemendikbud. Adapun alasan utamanya adalah; karena lokasi ini menggambarkan masalah yang telah diungkapkan dalam latar belakang masalah, sehingga patut untuk diteliti lebih lanjut.

Penelitian ini dilaksanakan dalam kurun waktu 4 minggu. Dengan memanfaatkan waktu sekolah siswa SD Rusyda yang dimulai dari hari Senin hingga Sabtu, pada jam 08.00 - 11.00. Data diperoleh dari guru-guru dan Kepala Sekolah dengan menggunakan waktu yang lebih fleksibel artinya tidak tepengaruh tehadap waktu belajar siswa.

Misalnya, mempergunakan waktu senggang, istirahat para guru untuk menanyakan hal-hal yang terkait dengan data penelitian. Namun pada hakikatnya, tetap juga menggunakan waktu guru 
ISSN 1979-9950 (print) || ISSN 2598-0033 (online), http://jurnal.umsu.ac.id/index.php/intiqad DOI: 10.30596/intiqad.v\% vi\%i.4469

Vol. 12, No. 1 (June 2020)

ketika mengajar. Sebab data yang akan diambil terkait kegiatan pembelajaran dalam implementasi pendidikan karakternya.

\section{Subjek Penelitian}

Subjek penelitian ini adalah guru khususnya guru mata Pelajaran PAI, Siswa-siswi SD Rusyda Medan, Kepala Sekolah, dan guru bidang ekstra kurikuler. Lebih rincinya dapat diperhatikan di bawah ini:

a. Guru Mata pelajaran Pendidikan Agama Islam

Menjadi sumber informasi terkait dengan kegiatan belajar mengajar PAI, dan implementasi pendidikan karakter yang terintegrasi dengan pelajarannya tersebut.

b. Siswa-Siswi SD Rusyda Medan Menjadi sumber informasi tentang objek yang menjadi tujuan dari implemenasi program penguatan pendidikan karakter.

c. Kepala Sekolah

Menjadi sumber informasi terkait berbagai dasar kebijakan penerapan program Penguatan Pendidikan Karakter di SD Rusyda Medan.

d. Guru Bidang Ekstra Kurikuler Menjadi sumber informasi tentang berbagai kegiatan yang dilakukan akan menjadi refensi tentang implementasi pendidikan karakter lewat jalur ini.

\section{Metode dan Pendekatan Penelitian}

Metode yang dipakai pada penelitian ini ialah kualitatif. Penelitian ini secara alami mencari, menggali, dan menemukan temuan-temuan baru terkait konsep, teori, dan pemahaman dari suatu kejadian atau latar yang berkonteks khusus. Dalam penelitian kualitatif ini fokusnya berada pada tataran memahami suatu masalah yang terjadi pada subjek penelitian, yang dalam konteks ini permasalahannya ialah keterampilan berbicara pada anak usia dini (Moloeng, 2007).

Jenis penelitian kualitatif menghendaki agar peneliti mampu untuk menguraikan dan menganalisis permasalahan secara holistik, dan alamiah. Maksud dari holistik ialah masalah dipahami dan dideskripsikan secara menyeluruh, dengan tidak ada satupun yang tertinggal dalam pembahasannya. Sedangkan secara alamiah, peneliti tetap menyajikan data temuan lapangan secara natural atau alamiah. Walaupun demikian, tidak dapat dipungkiri akan terdapat interpretasi peneliti.

Jenis penelitian kualitatif ini dipilih dengan alasan karena 
ISSN 1979-9950 (print) || ISSN 2598-0033 (online), http://jurnal.umsu.ac.id/index.php/intiqad DOI: 10.30596/intiqad.v\% vi\%i.4469

Vol. 12, No. 1 (June 2020)

karakteristik penelitiannya yang sangat menghendaki penguraian fakta yang terdapat di lapangan. Karena kualitatif menghendaki data yang terukur secara akurat dan cermat, maka penelitian kualitatif sangat membutuhkan kedalaman penggalian fakta dan data sebanyak-banyaknya.

Adapun pendekatan penelitian yang digunakan ialah pendekatan deskriptif, yakni pendekatan yang hanya sebatas pada pendeskripsian saja, atau dengan kata lain melukiskan kegiatan sebagaimana yang tampak ketika diamati. Pendekatan ini dipilih sebab impelementasi pendidikan karakter tersebut telah terlaksana, hanya tinggal meng-ekspose-nya saja ke publik, dan mencari beberapa kendala yang dihadapi saat penerapannya.

\section{Metode Pengumpulan Data}

Untuk mendapatkan data yang valid dan cocok dengan kebutuhan penelitian, maka akan ditempuh beberapa metode seperti yang tertera di bawah ini:

\section{a. Wawancara}

Wawancara dalam penelitian ini dilakukan terhadap para guru Pendidikan Agama Islam di SD Rusyda Medan, dan siswa-siswinya. Wawancara dilakukan tidak dalam ruangan tertutup melainkan

kondisional, artinya disesuaikan dengan waktu luang dari para informan penelitian.

Jenis wawancara yang dipilih ialah wawancara terstruktur, yaitu dengan menyusun daftar pertanyaan yang akan digunakan sebagai alat dalam wawancara dengan informan.

Untuk menunjukkan kealamiahan pada pelaksanaannya, hasil keterangan dari infoman tidak ditulis secara langsung dalam daftar pertanyaan, namun mempergunakan alat bantu rekaman, sehingga dipastikan semua informasi tidak ada yang tertinggal dan terlupakan.

\section{b. Observasi}

Observasi pada penelitian ini dilakukan dengan mencatat, ataupun merekam kejadian yang tampak secara nyata di lapangan. Pengamatan yang dimaksud ialah pengamatan langsung proses pembelajaran berbasis pendidikan karakter yang dilaksanakan di SD Rusyda, dan juga mengamati secara langsung tentang kendala yang dihadapi oleh anak di SD tersebut. Hasil pengamatan tersebut kemudian diinterpretasikan dengan susunan redaksi yang dibangun oleh peneliti. 


\section{c. Studi Dokumen}

Data dalam penelitian ini juga diperoleh melalui proses analisis terhadap dokumentasi yang berkaitan dengan implementasi program penguatan pendidikan karakter. Dalam hal ini, yang dilihat ialah RPP dan silabus para guru yang mengajar Pendidikan Agama Islam dan Ekstra Kurikuler, serta beberapa dokumen yang terkait dengan kebijakan pendidikan karakter.

\section{Teknik Analis Data}

Aktivitas analisis data yang dimaksud adalah aktivitas mengumpulkan, mengorganisasikan, dan memilih data yang penting untuk dapat ditarik kesimpulan. Dengan begitu dapatlah terungkap permasalahan yang menjadi rumusan atau fokus masalah (Moloeng, 2007).

\section{a. Reduksi data}

Kegiatan merangkum, memilih-milih dan focus pada data yang urgen untuk menemukan tema dan pola darinya. Aktivitas ini memberikan satu desksripsi yang cukup jelas dan juga membantu peneliti untuk mereduksi atau menghimpun data berikutnya. b. Model data (Data Display)

Menampilkan data dari yang telah dikumpulkan atau ditentukan polanya. Kegiatan ini bertujuan untuk mengorganisir, menyusun, atau mensistematisasi pola atau hubungan antar data, sehingga mudah untuk dimengerti (Moloeng, 2007). Bentuk display data yang dipilih ialah teks naratif (Emzir, 2010).

\section{c. Konklusi}

Konklusi atau menarik simpulan merupakan aktivitas menyimpulkan data-data yang telah terorganisir, sehingga data tersebut dapat dipahami secara utuh dan padu dalam satu kesatuan. Tentu saja prosesnya melalui penggabungan seluruh informasi yang tersusun dalam satu bentuk atau pola yang telah ditetapkan pada kegiatan display data. Penarikan simpulan ini menjadi satu kegiatan penting dan perlu kehati-hatian (Milles \& Huberman, 1992).

C. Hasil dan Pembahasan Penelitian

1. Hasil Penelitian

a. Implementasi Pendidikan

Karakter dalam Pembelajaran PAI 


\section{1) Deskripsi pada Perencanaan}

Implementasi pendidikan karaker dimulai dari kegiatan merencanakan pembelajaran. Perencanaan yang dilakukan dibuat setiap memasuki awal Tahun Pelajaran. Setiap pendidik menyusun Program Tahunan, Program Semester, membuat Silabus yang disertai dengan membuat Rencana Pelaksanaan Pembelajaran (RPP). Di dalam RPP tersebutlah tercantum setiap nilainilai karakter utama yang akan dibentuk atau ditargetkan di akhir pembelajaran. Nilai-nilai karakter ini dapat berbeda-beda sesuai dengan muatan materi pembelajaran.

Berikut ini disajikan data hasil rekaman wawancara dengan Kepala Sekolah, pendidik mata pelajaran PAI, dan juga didukung dengan data hasil observasi yang dilaksanakan terhadap perencanaan implementasi PPK di sekolah tersebut. Adapun hasilnya sebagai berikut :

Penuturan Kepala Sekolah : Tidak ada persiapan khusus, karena pendidikan karakter ini implisit, ya masuk di dalam proses pembelajaran di masing-masing mata pelajaran, maka administrasi ya secara umum sama dengan administrasi proses pembelajaran setiap mata pelajaran dimulai. Dari penyusunan silabus, RPP, analisis, penilaian dan sebagainya. (Kepala sekolah)

RPP itu dibuat di Awal Tahun Ajaran baru didalamnya memuat 5 muatan karakter sebagaimana amanah PPK yakni religious, nasionalis, integritas, madiri, gotong royong. Karakter itu dijabarkan dalam RPP termasuk juga apa nama kegiatan yang akan dilaksanakan untuk membentuk karakter itu (guru mapel PAI) (Mazid, 2019).

Data temuan hasil observasi yang dilaksanakan, bahwa setiap guru memang memiliki perangkat pembelajaran seperti Silabus, Prota, Prosem, dan RPP, baik berbentuk printout dan juga berbentuk Softcopy yang di dalamnya terdapat nilai-nilai karakter sebagaimana yang tecantum dalam Perpres tersebut.

2) Deskripsi pada Pengelolaan Kelas

Pengelolaan kelas berkarakter tidaklah sama dengan pengelolaan kelas sebagaimana biasa dilakukan. Pada pendidikan karakter, kelas dikelola sedemikian rupa sehingga menjadi media untuk menanamkan akhlak kepada para peserta didik. Di SD Rusyda Medan 
ini, para siswa duduk dengan model berkelompok, di antaranya dikelompokkan berdasarkan jenis kelamin. Siswa dan siswa tidak dibenarkan duduk sebangku, begitu juga sebaliknya, hal ini tidak hanya terjadi ketika pelajaran agama saja, melainkan terjadi pada seluruh mata pelajaran.

$$
\text { Pengelompokkan juga }
$$

dilakukan berdasarkan kemampuan siswa. Siswa dengan kemampuan rendah didudukkan bersama dengan teman dengan kemampuan di atasnya, hal ini bertujuan untuk dapat menerapkan pembelajaran tutor sebaya.

Sebagaimana dituturkan oleh guru mata pelajaran Agama Islam:

Siswa yang tidak pintar duduk bersama dengan sisswa yang pintar, dengan harapan siswa yang pintar dapat menularkan ilmunya kepada rekan-rekannya, hal inilah yang biasa kita sebut dengan metode tutor sebaya (Kamil, 2019).

\section{3) Deskripsi tentang Pemilihan Metode Pendidikan}

Metode pembelajaran yang dipilih oleh pendidik ketika menjelaskan pelajaran sangatlah bervariasi. Pada pembelajaran yang penekanannya pada aspek kognitif, para guru biasa menggunakan metode ceramah, diskusi, membaca kitab, dan lain-sebagainya. Namun untuk metode pada aspek afektif khusus untuk guru PAI, biasa menerapkan metode pembiasaan, metode hiwar, dan metode keteladanan.

Selain itu karakter juga ditanamkan melalui tiga hal, yakni (1) Spontanitas, dikatakan spontanitas karena memang karakter ditanamkan melalui kegiatan-kegiatan spontan, seperti memberikan pujian spontan, menunjukkan karakter spontan, bahkan penilaianpun dilakukan dengan melihat pada perilaku spontan yang dilakukan siswa.

Pembiasaan, maksudnya dilakukan dengan cara membiasakan siswa pada karakter-karakter tertentu. Religious misalnya, siswa dibiasakan untuk berdoa terlebih dahulu, mengucapkan kalimat thoyyibah, membaca AlQuran sebelum memulai pembelajaran, menutup aurat, membaca asmaul husna, dll. (3) Keteladanan, maksudnya guru menjadi sentral keteladanan bagi siswa. Apa yang menjadi perilaku guru, itulah yang menjadi tiruan oleh para siswa. Oleh karena itu di 
pesantern ini terdapat beberapa larangan perilaku secara general, yakni; tidak boleh memakai celana Jeans ketika mengajar, tidak boleh memakai anting, gelang, dan acsesoris mencolok lainnya. Tidak boleh merokok, dan harus memakai peci atau kupiah bagi laki-laki, dan diharuskan memakai jilbab yang menutup dada bagi wanita.

\section{4) Evaluasi Pendidikan Karakter}

Evaluasi dalam pembelajaran digunakan untuk mengetahui tingkat keberhasilan guru dalam menyampaikan materi ajar kepada siswa. Dalam pembelajaran, penilaian dilihat dari tiga aspek yaitu kognitif, afektif, dan psikomotor. Penilaian tersebut harus dilakukan supaya tujuan pembelajaran menjadi seimbang. Tidak hanya mementingkan satu aspek saja, sehingga tujuan pendidikan nasional dapat tercapai.

Evaluasi dalam pendidikan tentu dipakai untuk menganalisis sejauhmana tingkat keberhasilan pengajar dalam menghantarkan materi pelajaran kepada siswa, dalam pembelajaran tentu akan dianalisis dari tiga aspek yakni pengetahuan, sikap, serta keterampilan. Ketiga-tiga aspek itu harus didapatkan peserta didik secara proporsional dan seimbang.

Khusus untuk pendidikan karakter, maka penguatan pendidikan karakter dievaluasi melalui pengamatan guru terhadap perilaku siswanya. Akan diukur sudah sejauh mana tingkat perubahan tingkahlaku siswa dan sudah sejauh mana tertanam sikap-sikap tersebut pada siswa. Hal ini dapat dilihat dari kebiasaan-kebiasaan yang dilakukan siswa di kelas.

\section{b. Implementasi Program Penguatan Pendidikan Karakter di Luar Pembelajaran}

Di luar pembelajaran di SD Rusyda, penguatan pendidikan karakter dilakukan melalui berbagai kegiatan ekstra kurikuler, seperti kegiatan Pramuka, Nasyid, Majelis kerohanian Islam, dan Drumband. Kegiatan ini di tidaklah menjadi kewajiban. Artinya bagi siswa yang ingin mengikuti dipersilahkan, bagi yang tidak, juga tidak akan dipaksa.

Dalam kegiatan ini tentu terdapat banyak kegiatan yang menunjang terbentuknya karakter seorang siswa, seperti kemandirian, keberanian, gotong 
royong, integritas, religious dan sebagainya. Tentu kegiatan ini tidaklah diprogramkan khusus untuk mendidik karakter-karakter tersebut, tetapi secara tidak langsung bahkan kadang tidak disadari siswa, bahwa ia sedang mendapatkan asupan penanaman karakter oleh guru atau pembimbingnya.

Kegiatan ini hanya dilakukan satu kali dalam seminggu. Setiap siswa diperkenankan untuk mengikuti satu jenis kegiatan ekstra kurikuler saja.

\section{c. Kendala Yang Dihadapi dalam}

\section{Implementasi Program Penguatan}

\section{Pendidikan Karakter di TK}

\section{Rusyda Medan}

Terdapat beberapa kendala yang dihadapi dalam mengimplementasikan program ini, diantaranya ialah:

1) Tidak semua guru mendapatkan sosialisasi dan pelatihan tentang penerapan program Penguatan Pendidikan Karakter oleh Kementerian Pendidikan. Sehingga bagi guru yang belum mendapatkan pelatihan tentu akan menemui kesulitan.

2) Kurangnya kerjasama antar guru. Meskipun secara umum memang pendidikan karakter banyak menjadi tanggung jawab guru PAI dan PKn namun bukan berarti guru lain tidak bertanggungjawab terhadap pendidikan karakter anak didik.

3) Kurangnya kerjasama dengan orang tua. Pendidikan karakter tentu akan berjalan sesuai target, apabila orang tua juga memberikan support terhadap perkembangan sikap anak. Jika hanya pada guru saja, maka tentu tidak akan tercapai dengan maksimal. Terbukti dalam hal ini, SD Rusyda selalu memanggil orang tua untuk hadir namun selalu saja ada orang tua yang tidak hadir.

\section{Pembahasan}

Program Penguatan Pendidikan karakter pada dasarnya tidaklah menghendaki pelajaran yang mengkhususkan diri kepada karakter. Akan tetapi terintegrasi dengan pelajaran-pelajaran yang sudah ada. Namun tidaklah dapat dipungkiri bahwa, pada setiap jenjang pendidikan baik Dasar dan Menengah, Pendidikan Agama Islam dan Pendidikan Kewarganegaraan menjadi pelajaran yang menjadi ujung tombak dalam penanaman karakter peserta didik.

Hal itu bukan berarti bahwa mata pelajaran lain tidak turut serta dalam menanamkan karakter pada peserta 
didik. Pelajaran Olah raga misalnya, banyak orang menganggap pelajaran ini tentu bermuatan materi tentang kebugaran fisik, tetapi pada hekikatnya penguatan pendidikan karakter menghendaki 4 hal untuk pencapaian karakter yang paripurna, yakni olah rasa, olah karsa, olah hati dan olah raga.

Dalam pelaksanaanya Penguatan Pendidikan Karakter dalam pembelajaran PAI tentu tidaklah sulit untuk mengimplementasikannya. Seperti yang telah dijelaskan di atas bahwa program Penguatan Pendidikan Karakter dilakukan pada tiga ruang lingkup yakni Intra Kurikuler, Kokurikuler, dan Ekstrakurikuler.

$$
\text { Pada dasarnya pelaksanaan }
$$

Pendidikan Agama Islam mencakup tiga ruang lingkup tersebut. Pada lingkup intrakurikuler tentu melalui materi Pendidikan Agama Islam itu sendiri, yaitu materi akidah akhlak, fikih, sejarah kebudayaan Islam dan Alquran Hadits. Di dalam materi tersebut terdapat nilainilai spiritual yang pada dasarnya mengajarkan kebaikan kepada peserta didik, yang sejalan dengan program Penguatan Pendidikan Karakter itu sendiri.

\footnotetext{
Selain itu Pendidikan Agama Islam juga dapat terwujud dalam
}

kegiatan ekstra kurikuler, seperti Pramuka, majelis krohanian Islam, drum band, pembinaan bakat keislamanan dan lain sebagainya. Kegiatan ini juga dapat dijadikan sebagai ajang untuk penanaman karakter kepada peserta didik, seperti karakter kemandirian, kepemimpinan, gotong royong, semangat bekerja, toleransi, saling menghormati dan sebagainya.

Dalam hal penggunaan metode para guru dapat mempergunakan beberapa metode yang berkenaan dengan ranah sikap, seperti metode keteladanan dan metode pembiasaan. Karakter pada dasarnya tidak cukup hanya diajarkannya, melainkan yang paling penting ialah ditanamkan. Tentunya, proses penanaman itu dapat dilakukan dengan dua cara yakni keteladanan dan pembiasaan. Dengan terbiasa melakukan karakter-karakter terpuji maka dengan sendirinya secara tidak langsung ia akan memahami, dan melaksanakannya dalam kehidupan sehari-hari.

\section{Penutup}

Pendidikan karakter di SD Rusyda medan memang telah dilaksanakan sesuai dengan ketentuan Peraturan Presiden No. 87 tahun 2017. Secara 
implisit dilaksanakan dalam kegiatan pembelajaran, yakni terintegrasi dalam aktivitas pembelajaran di kelas. Pembinaan karakter juga dilaksanakan dalam kegiatan di luar pembelajaran, misalnya dalam kegiatan upacara bendera atau upacara kegiatan nasional lainnya. Selain itu, di luar pembelajaran juga dilakukan melalui kegiatan ekstrakurikuler. Seperti kegiatan Pramuka, Beladiri, Seni dan lainnya. Dalam kegiatan pembelajaran, tampak bahwa nilai-nilai tersebut tertera diperangkat pembelajaran para pendidik. Hal itu menunjukkan bahwa nilai tersebut menjadi target pencapaian pembelajaran. Tentu saja yang terpenting dalam implementasi ini semua adalah bahwa guru SD Rusyda Medan menjadi contoh teladan bagi siswa-siswanya, sebab tanpa itu semua maka kegiatan pembinaan karakter akan berjalan tidak seimbang dan proporsional. Kendala yang dihadapi ialah kurangnya pelatihan dari kementerian pendidikan tentang program Penguatan Pendidikan Karakter, kurangnya kerjasama guru dan orang tua tentang pendidikan karakter.

\section{E. Daftar Pustaka}

Chaniago, A. (2015). Lampiran Rencana Pembangunan Jangka Menengah Nasional 2015-2019; Buku I: Agenda Pembangunan Nasional. Jakarta .

Emzir. (2010). Metodologi Penelitian Kualitatif Analisis Data. Jakarta: Rajawali Press.

Kamil, R. (2019, November 07). Model Pengelompokan Siswa. (Haidir, Interviewer)

Koesoema, D. (2007). Pendidikan Karakter Strategi Mendidik Anak di Zaman Global. Jakarta: PT. Gramedia.

Lubis, R. R. (2018). Optimalisasi Kecerdasan Spiritual Anak. Jurnal Al-Fatih, 1(1), 1-18.

Lubis, R. R. (2019). Implementasi, Program Penguatan Pendidikan karakter (PPK) dalam pembelajaran Penddikan afama Islam. Al-Fikru, 12(1), 21.

Majid, A., \& Andayani, D. (2011). Pendidikan Karakter Perspektif Islam. Bandung: PT Remaja Rosdakarya. 
Mazid, A. (2019, November 07).

Persiapan Khusus dalam

Pendidikan Karakter . (Haidir,

Interviewer)

Milles, M. B., \& Huberman, M. A. (1992). Analisis Data Kualitatif.

(R. Rohidi, Trans.) Jakarta: UI

Press.

Moloeng, L. J. (2007). Metodologi

Penelitian Kualititatif. Bandung:

Remaja Rosdakarya.

Nurussakinah Daulay, (2019). The Dynamic Of Islamic Education in South East Asia . Seminar of International (pp. 146-147).

Medan: Perdana Publishing.

Sekolah, K. (2019, November 07).

Persiapan Khusus dalam

Pendidikan Karakter. (Haidir,

Interviewer)

Wibowo, A. (2012). Pendidikan

Karakter: Strategi Membangun

Karakter Bangsa Berperadaban.

Yogyakarta: Pustaka Pelajar. 